\title{
EVALUASI HUBUNGAN DUKUNGAN KELUARGA DAN KUALITAS HIDUP PENDERITA DIABETES MELITUS TIPE 2 : LITERATUR REVIEW
}

\author{
Rensi R. Runtuwarow ${ }^{1}$, Mario E. Katuuk ${ }^{2}$, Reginus T. Malara ${ }^{3}$ \\ 1,2,3 Program Studi Ilmu Keperawatan Fakultas Kedokteran Universitas Sam Ratulangi \\ Email : rensi.runtuwarow@gmail.com
}

\begin{abstract}
Diabetes mellitus (DM) is a serious public health problem. Where this disease is one of the highest diseases of the four non-communicable diseases. In this DM disease if not treated properly will produce in complications with serious illness. Objective. The purpose of this study was to evaluate the relationship between family support and the quality of life of people with type 2 diabetes mellitus. The method. Used literature review to compile this literature review was to search through an electronic database. The article search was carried out using the keywords Family Support, Quality Of Life, Diabetes mellitus type 2, which was traced through Google Scholar and Pubmed. 945 articles were identified and published from 2015-20120. Out of 945 articles, only 4 articles met the requirements to be analyzed. Results. Based on the articles that have been reviewed show that family support is very important in overcoming the quality of life of people with type 2 diabetes and one in four articles found no results and three of the four articles information. Conclusion. Literature review evaluation results can be concluded from two major themes namely family support and quality of life having their respective categories obtained according to the analysis that researchers conducted. $90 \%$ of the results of these four articles show a relationship between family support and the quality of life of people with type 2 diabetes.
\end{abstract}

Keywords: Family Support, Quality of Life, Diabetes Mellitus Type 2.

\begin{abstract}
Abstrak
Diabetes Melitus (DM) merupakan masalah kesehatan masyarakat yang serius. Dimana penyakit ini menjadi salah satu penyakit tertinggi dari empat penyakit tidak menular. Pada penyakit DM ini apabila tidak ditangani dengan baik akan mengakibatkan timbulnya komplikasi dengan penyakit yang serius. Tujuan Penelitian untuk mengevaluasi hubungan dukungan keluarga dan kualitas hidup penderita diabetes mellitus tipe 2. Metode literature review, yang digunakan untuk menyusun tinjauan pustaka ini adalah dengan mencari melalui database elektronik. Pencarian artikel dilakukan dengan menggunakan kata kunci Family Support, Quality Of Life, Diabetes mellitus type 2 yang ditelusuri melalui Google Scholar dan Pubmed. Didapatkan 945 artikel yang diidentifikasi dan dipublikasikan dari tahun 2015-20120. Dari 945 artikel hanya 4 artikel yang memeuhi syarat untuk dianalisis. Hasil berdasarkan artikel-artikel yang telah ditinjau menunjukan bahwa dukungan keluarga sangat berperan penting dalam mengatasi kualitas hidup dari penderita DM tipe 2 dan satu dari empat artikel menemukan hasil tidak ada buhungan dan tiga dari keempat artikel memberikan hasil adanya hubungan. Kesimpulan hasil evaluasi tinjauan pustaka dapat
\end{abstract}


disimpulkan dari dua tema besar yaitu dukungan keluarga dan kualitas hidup memiliki kategorinya masing-masing yang diperoleh menurut analisis yang peneliti lakukan. 90\% hasil dari keempat artikel ini menunjukan adanya hubungan dukungan keluarga dan kualitas hidup penderita DM tipe 2.

Kata Kunci: Dukungan Keluarga, Kualitas Hidup, Diabetes Melitus Tipe 2

\section{PENDAHULUAN}

Diabetes Melitus (DM) merupakan masalah kesehatan masyarakat yang serius. Dimana penyakit ini menjadi salah satu penyakit tertinggi dari empat penyakit tidak menular. Berdasarkan laporan International Diabetes Federation (IDF) pada tahun 2019. Penyakit DM ini mengakibatkan 1 dari 10 orang dewasa diperkirakan setiap 6 detik 1 orang meninggal hasil menunjukan estimasi individu dengan penyakit DM di dunia melebihi angka 463 juta orang dan di perkirakan 578 juta orang $(10,2 \%$ dari populasi) akan menderita DM pada tahun 2030. IDF (2019) memperkirakan pada tahun 2045 jumlah penderita penyakit DM di dunia mencapai 700 juta orang. Berdasarkan Riset Kesehatan Dasar tahun 2018, Indonesia berada pada peringkat ke -5 di dunia, prevalensi DM di Indonesia berada pada kisaran angka 2\% dengan Provinsi Sulawesi Utara berada pada urutan ke empat dengan kisaran angka 3\%. Kemudian untuk daerah domisili lebih banyak penderita DM yang berada di perkotaan $(1,9 \%)$ dibandingkan dengan diperdesaan $(1,0 \%)$ (Badan Penelitian dan pengembangan Kesehatan, 2018). DM dikarakteristikan dengan adanya hiperglikemia yang dapat disebabkan oleh kurangnya sekresi insulin, ketidakmampuan kerja insulin, maupun keduanya (WHO, 2019).

Komplikasi pada DM dapat mengakibatkan komplikasi berupa akut maupun kronis. Pada penyakit DM ini apabila tidak ditangani dengan baik akan mengakibatkan timbulnya komplikasi dengan penyakit serius lainnya seperti jantung, stroke, disfungsi ereksi, gagal ginjal, dan kerusakan sistem syaraf dan faktor komplikasi yang bisa dialami penderita DM cukup bervariasi bisa disebabkan karna faktor fisik, psikologis dan sosial. Dalam menjalani pola hidup sehat penderita membutuhkan dukungan dari orang-orang sekitar terutama dukungan dari keluarganya sendiri. Keluarga memiliki peran yang sangat penting terhadap status kesehatannya, dengan penyakit akut ataupun kronis yang sedang dihadapinya. Menurut penelitian yang dilakukan Skarbec (2006) ditemukan bahwa peran keluarga mempunyai hubungan yang kuat terhadap status kesehatan penderita DM, dimana kurangnya dukungan keluarga akan mempengaruhi kontrol gula darah dan menajemen DM sehingga kualitas hidup akan menurun. Dapat disimpulkan bahwa dukungan keluarga sangat penting dan berpengaruh terhadap kualitas hidup penderita DM. Penderita yang mendapatkan dukungan keluarga cenderung lebih mudah melakukan perubahan perilaku kearah lebih sehat daripada penderita yang kurang mendapatkan dukungan dari orang sekitar (Friedman, et al 2010).

Dukungan keluarga adalah sikap, tindakan dan penerimaan keluarga terhadap penderita yang sakit. Dukungan bisa berasal dari orang lain (orangtua, anak, suami, istri atau saudara) yang dekat dengan penderita dimana bentuk dukungan berupa informasi, tingkah laku tertentu atau materi yang dapat menjadikan individu merasa disayangi, diperhatikan dan dicintai (Ali, 2009).

Dukungan keluarga pada penderita DM diharapkan turut membantu keberhasilan penatalaksanaan DM, sehingga dapat 
menghindari terjadinya komplikasi dan meningkatkan kualitas hidup penderita penyakit DM ini akan menyertai seumur hidupnya sehingga dapat mempengaruhi kualitas hidup penderita. Hidup dengan DM dapat mempengaruhi keadaan hidupnya yang sering disebut dengan pengaruh negatif terhadap kualitas hidup penderita baik atau tanpa komplikasi. Kualitas hidup dinyatakan sebagai ukuran konseptual atau operasional mencakup kesejahteraan, kualitas kelangsungan hidup serta kemampuan untuk secara mandiri melakukan aktivitas seharihari yang sering digunakan dalam situasi penyakit akut ataupun kronik sebagai cara untuk menilai dampak terapi pada penderita (Brooker, 2008).

Penelitian dari Ningrum (2018) mengatakan dukungan keluarga dapat mempengaruhi kepuasan seseorang dalam menjalani kehidupan sehari-hari dimana peran keluarga sangat penting dalam setiap aspek perawatan kesehatan keluarga mulai dari strategi hingga fase rehabilitasi. Salah satu sasaran terapi pada DM adalah peningkatan kualitas hidup. Kualitas hidup seharusnya menjadi perhatian penting bagi semua orang karena dapat menjadi acuan keberhasilan dari suatu tindakan intervensi atau terapi. Penyakit DM ini dikatakan akan menyertai seumur hidup penderita sehingga sangat mempengaruhi kualitas hidup seseorang. Jika tidak ditangani dengan baik dapat menimbulkan komplikasi serius yang akan membahayakan jiwa penderita dan mempengaruhi kualitas hidupnya. Kualitas hidup yang rendah dapat memperburuk komplikasi dan dapat berakhir kecacatan atau kematian. (Skevigton et al 2006).

Penelitian sebelumnya yang dilakukan oleh Rahmawati (2014) bahwa dukungan keluarga memberikan pengaruh terhadap kualitas hidup sebesar $40,3 \%$ pada pasien DM, dimana dukungan keluarga yang memadai akan meningkatkan kesehatan fisik penderita
DM dengan menurunkan gejala depresi. Selain itu, dukungan keluarga juga dapat meningkatkan kemampuan adaptif dari kognitif termasuk meningkatkan optimisme penderita DM, mengurangi kesepian dan meningkatkan kemampuan diri dalam pengelolaan DM. Hal ini akan menurunkan risiko komplikasi dan meningkatkan kualitas hidupnya. Dengan kata lain, semakin tinggi dukungan keluarga baik dalam bentuk emosional, instrumental, penghargaan, dan informasi maka akan semakin tinggi pula kualitas hidup penderita DM. Dukungan keluarga yang rendah akan sangat berpengaruh terhadap kualitas hidup bagi penderita DM karena tidak banyak orang yang menderita DM yang memiliki dukungan dari orang-orang sekitarnya terutama dari keluarganya sendiri, penderita akan merasa kurangnya mendapat perhatian dari keluarga dan merasa tidak dipedulikan oleh keluarganya dan itu akan menyebabkan kualitas hidup penderita DM akan menurun bahkan berakibat buruk bagi penderita. Berdasarkan beberapa hasil penelitian yang telah dipaparkan, peneliti bertujuan membuat tinjauan terhadap berbagai hasil penelitian tentang dukungan keluarga dan kualitas hidup penderita DM tipe 2. Tinjauan kepustakaan atau literature review juga sangat memungkinkan untuk dilakukan pada penelitiaan kali ini karena mengingat kondisi saat ini penelitian yang tidak memungkinkan untuk melakukan penelitian di fasilitas kesehatan yaitu dalam hal ini di Rumah Sakit, serta tidak diperbolehkan untuk kontak langsung dengan masyarakat karena daerah penelitian yang sementara dilanda Pandemi Covid-19. Maka dari itu penulis tertarik untuk melakukan tunjauan pustaka dari hasilhasil penelitian yang peneliti temukan diberbagai database mengangkat topik penelitian terkait dengan dukungan keluarga dan kualitas hidup penderita DM tipe 2. Tujuan dari tinjauan pustaka ini adalah dievaluasi hubungan dukungan keluarga dan 
kualitas hidup penderita diabetes mellitus tipe 2.

\section{METODE PENELITIAN}

Desain penelitian ini adalah Literature Review atau tinjauan pustaka. Studi literature review adalah cara yang dipakai untuk megumpulkan, mencari, memeriksa dan membahas data atau sumber yang berhubungan pada sebuah topik tertentu yang bisa didapat dari berbagai sumber seperti jurnal, buku, internet, dan pustaka lainnya.

Data yang digunakan dalam penelitian ini berasal dari hasil-hasil penelitian yang sudah dilakukan dan diterbitkan dalam jurnal online nasional dan internasional. Dalam melakukan penelitian ini peneliti melakukan pencarian jurnal penelitian yang dipublikasikan di internet menggunakan PubMed dan Google Schoolar dengan kata kunci pencarian yaitu: Dukungan Keluarga (Family Support), Kualitas Hidup (Quality Of Life), Diabetes Melitus Tipe 2 (Diabetes Mellitus Type 2).

Adapun kriteria pengumpulan jurnal insklusi adalah a. Artikel atau jurnal yang membahas sesuai topik. b. Literature review ini menggunakan literatur terbitan 5 tahun terakhir ( 2015-2020) yang dapat diakses fulltext dalam format pdf. c. Kriteria jurnal yang direview adalah artikel penelitian berbahasa Indonesia dan Inggris dengan subjek manusia dewasa dengan rentang usia 30 tahun ke atas dengan menderita DM tipe 2. d. Artikel Jurnal Penelitian Primer yang menggunakan disain penelitian: Cross Sectional. Analisa data dapat dilakukan dengan cara melakukan kompilasi dari setiap artikel yang didapat dan menyederhanakan setiap temuan. Tinjauan pustaka ini merupakan Systematic Literature Review dengan menggunakan JBI Critical Appraisal atau Case Series untuk menyaring artikel yang ditemukan. Artikel yang terkumpul dianalisis dengan menggunakan metode
Simplified Approach yang merupakan bagian dari Thematic Analysis Menurut Aveyard (2014) pendekatan tematik adalah menyimpulkan literatur yang relevan untuk yang baru memulai melakukan penelitian Literatur Review. Metode ini disederhanakan dan disesuaikan dengan ide-ide yang dihasilkan dari karya peneliti.

\section{HASIL DAN PEMBAHASAN}

Jumlah artikel awal yang didapat dari kedua database tercatat sebanyak 945 artikel. Selanjutnya penulis melakukan screening berdasarkan kriteria inklusi dan eksklusi pada artikel-artikel tersebut. Dari total 945 artikel, penulis mengeksklusi 941 artikel.

a. Excluded by title/abstract : 795 Tidak memberikan keterangan desain penelitian, tidak berbahasa Indonesia dan Inggris, tidak berkaitan dengan dm tipe 2. Menghasilkan 150 artikel.

b. Excluded by full text : 98 Hasil dan pembahasan tidak mencantumkan karakteristik responden dengan jelas, tidak ada abstarak dan menghasilkan 52 artikel.

c. Excluded dari analisis data : 48 Tidak mencantumkan rentang usia, usia dibawah umur 30 tahun dan tidak sesuai judul sehinggah ditemukan pencarian terakhir 4 artikel.

Peneliti melakukan critical appraisal terhadap empat artikel yang akan digunakan. Peneliti menggunakan format critical appraisal checklist for crossectional studies yang dikembangkan oleh Joanna Briggs Institute untuk menentukan kualitas suatu artikel. Berdasarkan format tersebut ke empat artikel yang telah diperoleh layak untuk digunakan dalam kajian literatur ini karena ke empat artikel yang diperoleh.

Hasil seleksi artikel studi digambarkan dalam Diagram Flow. 


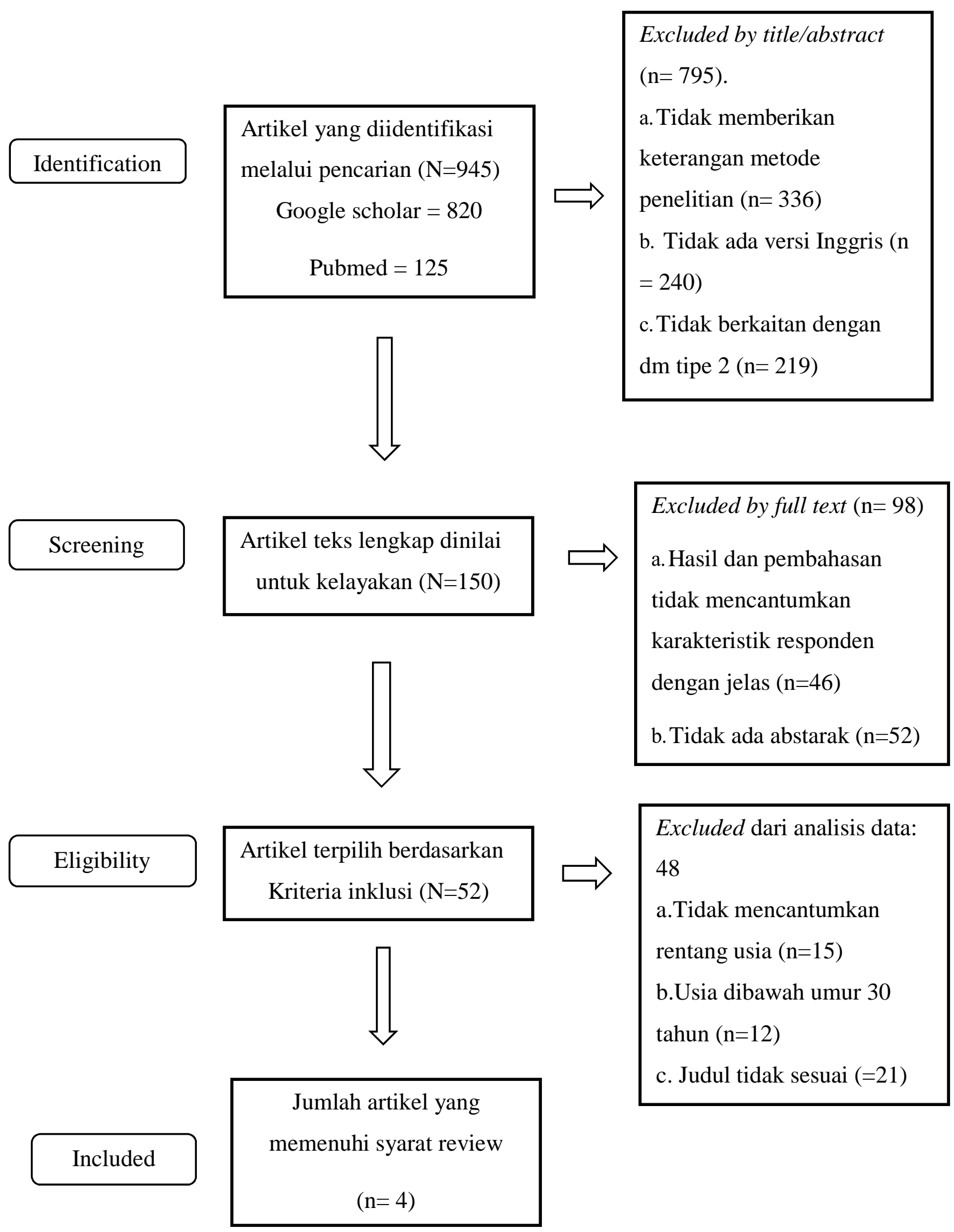


Ringkasan Artikel

$\begin{array}{llccc}\text { Penulis/tahun } & \text { Judul } & \begin{array}{c}\text { Tujuan } \\ \text { penelitian }\end{array} & \begin{array}{c}\text { Desain } \\ \text { penelitian }\end{array} & \text { Hasil }\end{array}$

\begin{tabular}{lll} 
Ketut & Hubungan & \multicolumn{2}{l}{ Untuk mengetahui } \\
Suardana & Dukungan & hubungan dukungan \\
(2015) & Sosial, Keluarga & sosial d keluarga \\
& Dengan Kualitas & dengan kualitas hidup \\
& Hidup Pasien & pasien DM Tipe 2 \\
& Dabetes Melitus & \\
& Tipe 2 &
\end{tabular}

Pendekatan
crossectional

$\begin{array}{lr}\text { Dukungan } & \text { sosial } \\ \text { keluarga dan } & \text { kualitas } \\ \text { hidup pasien DM yaitu } & \text { Dukungan } \\ \text { Dosial }\end{array}$ keluarga diperoleh hasil terbanyak dengan jumlah sampel sebanyak 40 responden yang memenuhi kriteria inklusi dengan katagori baik (95\%). Kualitas hidup pasien DM diperoleh hasil terbanyak dengan katagori baik yaitu $(75 \%)$. Hal ini berarti bahwa dukungan keluarga sangat diperlukan oleh individu dalam mengatasi masalah yang dialami, karena keluarga merupakan hubungan sosial yang terdekat dengan seseorang. Tidak ada hubungan dukungan social keluarga dengan kualitas hidup pasien DM.

\begin{tabular}{|c|c|c|c|c|}
\hline $\begin{array}{l}\text { Samantha } \\
\text { Ramkisson } \\
\text { (2017) }\end{array}$ & $\begin{array}{l}\text { Social support } \\
\text { and coping in } \\
\text { adults with type } 2 \\
\text { diabetes }\end{array}$ & $\begin{array}{l}\text { Mengeksplorasi } \\
\text { apakah pasien dengan } \\
\text { persepsi sosial yang } \\
\text { buruk } \\
\text { dukungan memiliki } \\
\text { tingkat kesejahteraan } \\
\text { dan koping yang lebih } \\
\text { rendah daripada } \\
\text { pasien dengan } \\
\text { dukungan sosial yang } \\
\text { baik bagi dm tipe } 2 .\end{array}$ & $\begin{array}{l}\text { Pendekatan } \\
\text { crossectional }\end{array}$ & $\begin{array}{lr}\text { Pentingnya, dukungan } \\
\text { social keuarga dalam } \\
\text { membantu pasien } \\
\text { dengan DM dan untuk } \\
\text { meningkatkan kepatuhan } \\
\text { terhadap pengobatan. } \\
\text { Penyedia r layanan } \\
\text { kesehatan r perlu } \\
\text { mengambil kesadaran } \\
\text { psikososial } \\
\text { faktor dalam pengobatan } \\
\text { pasien ralam }\end{array}$ \\
\hline
\end{tabular}




\begin{tabular}{|c|c|c|c|c|}
\hline & & & & $\begin{array}{l}\text { manajemen DM untuk } \\
\text { memfasilitasi } \\
\text { kelompok pendukung } \\
\text { untuk anggota keluarga } \\
\text { dan memberikan } \\
\text { intervensi } \\
\text { untuk pasien DM dan } \\
\text { keluarga agar kualitas } \\
\text { hidup a penderita } \\
\text { meningkat. Total sampel } \\
\text { terdiri dari } 401 \text { peserta, } \\
\text { 200 dari sektor } \\
\text { kesehatan swasta dan } \\
201 \text { dari masyarakat } \\
\text { sektor kesehatan. }\end{array}$ \\
\hline $\begin{array}{l}\text { Susi } \\
\text { Oktowaty } \\
(2018)\end{array}$ & $\begin{array}{l}\text { Hubungan } \\
\text { Fungsi Keluarga } \\
\text { Dengan Kualitas } \\
\text { Hidup Pasien } \\
\text { Penyakit Kronis }\end{array}$ & $\begin{array}{l}\text { Penelitian ini untuk } \\
\text { mengetahui hubungan } \\
\text { fungsi keluarga } \\
\text { dengan kualitas hidup } \\
\text { pasien penyakit } \\
\text { kronis DM. }\end{array}$ & $\begin{array}{l}\text { Pendekatan } \\
\text { crossectional }\end{array}$ & $\begin{array}{l}\text { Penelitian ini responden } \\
\text { yang mempunyai } \\
\text { kualitas hidup sebagian } \\
\text { besar memiliki fungsi } \\
\text { keluarga yang sangat } \\
\text { baik } 150 \text { peserta yang } \\
\text { memenuhi kriteria } \\
\text { inklusi penelitian yaitu } \\
\text { bersedia } \\
\text { menjadi responden. Hal } \\
\text { ini memperlihatkan } \\
\text { adanya hubungan } \\
\text { bermakna } \\
\text { antara fungsi keluarga } \\
\text { dengan kualitas hidup, } \\
\text { baik dari aspek } \\
\text { kesehatan fisik, } \\
\text { psikologis, } \\
\text { hubungan sosial dan } \\
\text { lingkungan. Hubungan } \\
\text { sosial meliputi hubungan } \\
\text { personal dan dukungan } \\
\text { sosial termasuk } \\
\text { dukungan keluarga } \\
\text { menjadi } \\
\text { salah satu aspek penting } \\
\text { dalam membangun } \\
\text { kualitas hidup. }\end{array}$ \\
\hline $\begin{array}{l}\text { Fatma } \\
\text { Nuraisyah } \\
(2017)\end{array}$ & $\begin{array}{l}\text { Family support } \\
\text { and quality of life } \\
\text { among patients }\end{array}$ & $\begin{array}{l}\text { Untuk mengetahui } \\
\text { hubungan antara }\end{array}$ & $\begin{array}{l}\text { Pendekatan } \\
\text { crossectional }\end{array}$ & Penelitian ini \\
\hline
\end{tabular}




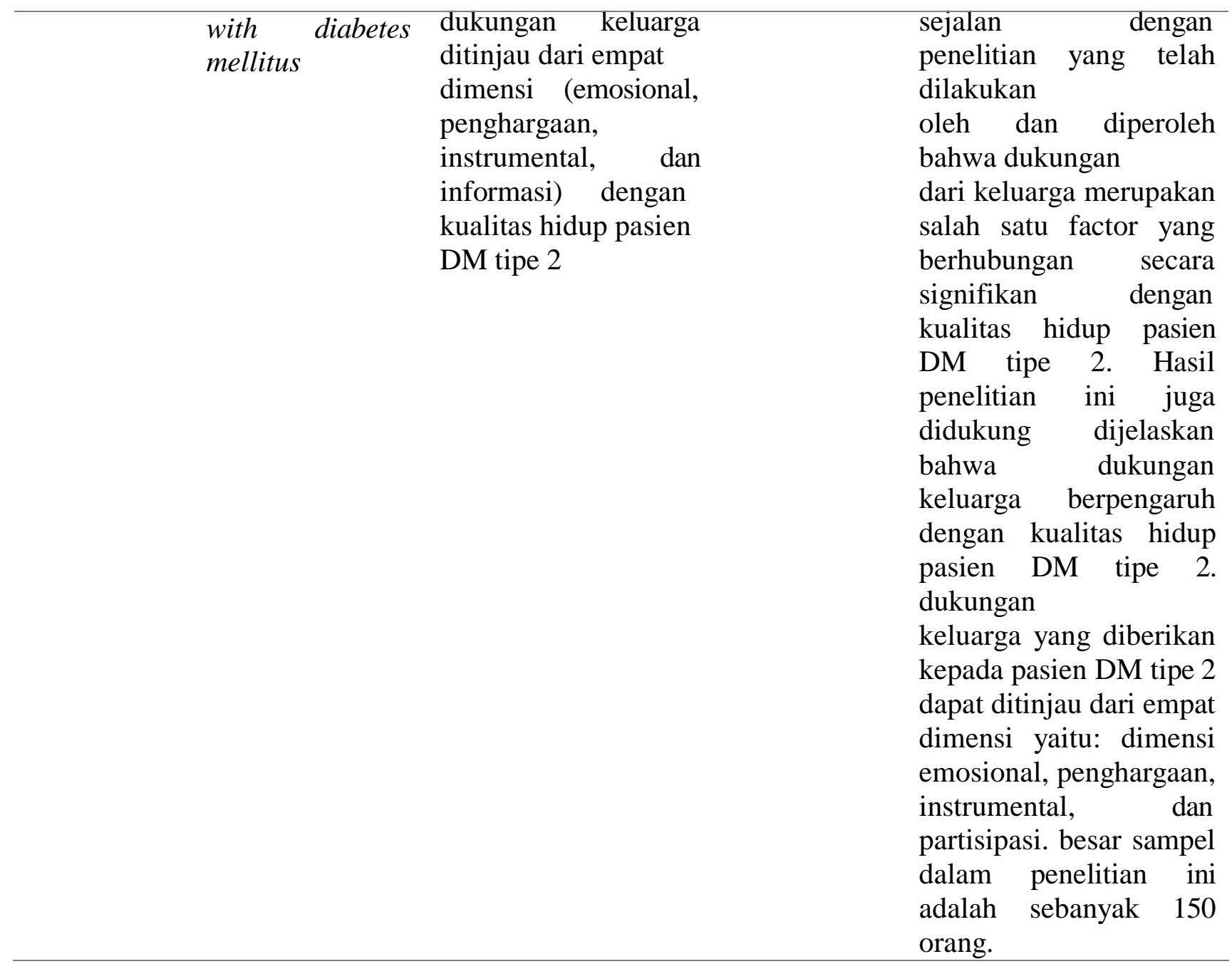

Berdasarkan analisis pada empat artikel yang telah didapatkan, maka terdapat dua tema besar terkait dukungan keluarga dan kualitas

Pengembangan Tema hidup penderita DM tipe 2 seperti yang digambarkan pada tabel di bawah ini.

\section{Artikel}

Subtema
Pengelompokan

Tema
Tema Besar

Dukungan

Keluarga

Diabetes Melitus Tipe 2

- Dukungan social

- Keluarga

- Kualitas Hidup

- Diabtes Melitus

tipe 2

- Family Support

- Coping 


\begin{tabular}{lll}
\hline & - Diabetes & \\
& Mellitus Type 2 & \\
\hline Artikel 3 & - Family Support \\
& - Quality Of Life \\
& - Diabetes & \\
& Mellitus & Kualitas Hidup \\
Artikel 4 & - Fungsi Keluarga \\
& - Kualitas Hidup \\
& \\
& - Penyakit Kronis \\
\hline
\end{tabular}

\section{PEMBAHASAN}

Artikel pertama dengan judul Hubungan Dukungan Sosial, Keluarga Dengan Kualitas Hidup Pasien Dabetes Melitus Tipe 2 (2018) Dukungan keluarga yang tinggi tentunya akan memberikan ketenangan dan kenyamanan pada pasien DM tersebut. Dukungan social keluarga yang adekuat terbukti berhubungan dengan menurunnya mortalitas lebih mudah sembuh dari sakit, dan kesehatan emosi. Dukungan keluarga yang diterima seseorang dapat berupa dukungan informasional, perhatian, fasilitas/instrumental, dan dukungan emosional. Dari hasil analisis proporsi dukungan emosional keluarga yang dirasakan responden sebagian besar baik $(92,5 \%)$, sebanyak $5 \%$ kurang dan 2,5\% cukup. Hal ini sesuai dengan konsep dukungan keluarga yaitu suatu bentuk hubungan interpersonal meliputi sikap, tindakan, dan penerimaan keluarga terhadap seseorang, sehingga orang tersebut merasa ada yang memperhatikan, menghargai dan mencintai, sehingga terhindar dari efek stress yang buruk. Keluarga sebagai sebuah tempat yang aman dan damai untuk istirahat dan pemulihan serta membantu penguasaan terhadap emosi. Setiap orang pasti membutuhkan bantuan afeksi dari orang lain, dukungan ini berupa dukungan simpatik dan empati, kepercayaan dan penghargaan. Proporsi dukungan penghargaan/perhatian keluarga yang dirasakan responden semuanya baik (100\%).
Keluarga bertindak sebagai sebuah bimbingan umpan balik, membimbing dan menengahi pemecahan masalah, serta sebagai sumber dan validator identitas anggota keluarga. Dukungan perhatian juga merupakan suatu bentuk penghargaan yang diberikan kepada seseorang, bisa berupa penghargaan positi pada individu, pemberian semangat, persetujuan pada pendapat individu, perbandingan yang positif dengan individu lain. Proporsi dukungan fasilitas/instrumental keluarga yang dirasakan responden sebagian besar baik (75\%) dan $25 \%$ cukup. Keluarga merupakan sebuah sumber pertolongan praktis dan konkrit, diantaranya dalam hal pengawasan, keteraturan pengobatan, kebutuhan kesehatan penderita seperti makan dan minum, istirahat dan tidur. Fasilitator mencari sarana kesehatan yang tepat sehingga individu merasa ada perhatian dan kepedulian yang nyata dari lingkungannya. Artikel kedua denan judul Social support and coping in adults with type 2 diabetes (2017), Hubungan terbalik antara dukungan social dan koping, yang menunjukkan bahwa peningkatan dukungan social dikaitkan dengan penurunan tekanan emosional.

Peserta yang melaporkan dukungan sosial tingkat tinggi pernah tingkat kesejahteraan yang lebih baik. Ada korelasi positif yang kecil antara GHQ dan HbA1c. Wanita dan pasien yang menghadiri fasilitas kesehatan sektor publik menunjukkan koping yang buruk. Hubungan terbalik antara dukungan sosial dan mengatasi menunjukkan bahwa 
peningkatan dukungan sosial terkait dengan penurunan tekanan emosional. Khusus emosional dukungan dikaitkan dengan penurunan tekanan emosional. Pasien yang mendukung dukungan sosial tingkat tinggi telah tingkat kesejahteraan yang lebih baik. Dukungan sosial khusus di Indonesia ketentuan situasi darurat dikaitkan dengan lebih baik tingkat kesejahteraan. Di sampel ini, sebagian besar peserta hidup dengan lima orang atau lebih, dan mayoritas sudah menikah. Mayoritas pasien menunjukkan bahwa sebagian besar dukungan datang dari pasangan mereka atau anggota keluarga lainnya.

Artikel ketiga dengan judul Hubungan Fungsi Keluarga Dengan Kualitas Hidup Pasien Penyakit DM Kronis (2018), responden yang mempunyai kualitas hidup sebagian besar memiliki fungsi keluarga yang sangat baik. Hal ini memperlihatkan adanya hubungan bermakna antara fungsi keluarga dengan kualitas hidup, baik dari aspek kesehatan fisik, psikologis, hubungan sosial dan lingkungan. Hubungan sosial meliputi hubungan personal dan dukungan sosial termasuk dukungan keluarga menjadi salah satu aspek penting dalam membangun kualitas hidup. Hasil penelitian Anikha pada Tahun 2015 di sebuah rumah sakit di Surabaya bahwa terdapat pengaruh dari dukungan keluarga terhadap kualitas hidup pasien disamping pengaruh status diabetes pada pasien penyakit ini memperlihatkan bahwa pentingnya intervensi keluarga pada pengelolaan pasien penyakit ginjal kronis dengan hemodialisis. Begitu juga pada penelitian Arianti yang menemukan adanya hubungan antara dukungan sosial dan kualitas hidup pada pasien. Salah satunya adalah berkolaborasi dan bekerjasama dengan keluarga atau pendamping pasien. Tujuannya untuk meningkatkan dukungan keluarga terhadap pengelolaan pasien. Pada penelitian menyatakan bahwa dukungan keluarga mempunyai pengaruh positif terhadap kualitas hidup pasien diabetes khususnya dalam bentuk dorongan (encouragement) dari keluarga. Dengan demikian fungsi keluarga akan bertambah baik dan kualitas hidup pasienpun meningkat.

Artikel keempat dengan judul Family support and quality of life among patients with diabetes mellitus (2017) Dukungan keluarga menunjukkan bahwa ada hubungan yang bermakna secara statistik antara dukungan dimensi penghargaan dengan kualitas hidup pasien DM II (p-value: 0,01) sehingga dapat dilakukan analisis selanjutnya. Hasil analisis multivariate menunjukkan bahwa adanya hubungan dukungan keluarga dengan kualitas hidup pasien DM tipe 2 (p-value: 0,00). Dukungan dari keluarga merupakan salah satu factor yang berhubungan secara signifikan dengan kualitas hidup pasien DM tipe 2. Hasil penelitian ini juga didukung dijelaskan bahwa dukungan keluarga berpengaruh dengan kualitas hidup pasien DM tipe 2. Kualitas hidup merupakan kapasitas fungsional psikologis dan kesehatan social serta kesejahteraan individu. Kualitas hidup dipengaruhi oleh kesehatan fisik, kondisi psikologis, tingkat ketergantungan hubungan sosial, dan hubungan pasien dengan lingkungan sekitarnya. Dijelaskan juga dukungan keluarga yang diberikan kepada pasien DM tipe 2 dapat ditinjau dari empat dimensi yaitu: dimensi emosional, penghargaan, instrumental, dan partisipasi. Penelitian ini juga sejalan dengan penelitian diperoleh bahwa aspek dari dukungan keluarga berkaitan dengan kadar glukosa darah dalam hal ini dapat mempengaruhi kualitas hidup pada pasien DM tipe 2. Peran keluarga merupakan salah satu aspek penting dimana dapat mempengaruhi kondisi kesehatan psikologis, sosial, emosional bagi individu. 


\section{Dukungan Keluarga Pada Penderita Diabetes Melitus Tipe}

Temuan pertama yang dilakukan oleh Suardana1 K. (2018) sebagian besar subyek penelitian merasakan dukungan keluarga baik yaitu sebesar 95\%. Hal ini berarti bahwa dukungan keluarga sangat diperlukan oleh individu dalam mengatasi masalah yang dialami, karena keluarga merupakan hubungan sosial yang terdekat dengan seseorang. Walaupun pasien masih tinggal bersama keluarganya, kondisi penyakit kronis yang dialami pasien sanngat membutuhkan dukungan dari sanak keluarganya. Dukungan keluarga yang tinggi tentunya akan memberikan ketenangan dan kenyamanan pada pasien DM tersebut.

Temuan kedua yang dilakukan oleh Ramkisson S. (2017) Hasil penelitian ini dijelaskan bahwa dukungan keluarga berpengaruh terhadap pasien DM II Dijelaskan juga dukungan keluarga yang diberikan kepada pasien DM II dapat ditinjau dari empat dimensi yaitu: dimensi emosional, penghargaan, instrumental, dan partisipasi. Penelitian ini diperoleh bahwa aspek dari dukungan keluarga berkaitan dengan kadar glukosa darah dalam hal ini dapat mempengaruhi kualitas hidup pada pasien DM II. Peran keluarga merupakan salah satu aspek penting dimana dapat mempengaruhi kondisi kesehatan psikologis, sosial, emosional bagi individu.

Temuan keempat ini yang dilakukan oleh Susi Oktaviani (2017) Responden pada penelitian ini sebagian besar tinggal di rumah sendiri beserta keluarga inti, yaitu anak dan cucunya. Dengan demikian peran keluarga sangat besar dirasakan oleh para responden dalam menjalankan kehidupan sehariharinya. Dukungan keluarga merupakan salah satu unsur penting dalam membangun fungsi keluarga pada penilaian APGAR Keluarga. Hasil analisis menggambarkan bahwa keluarga fungsional cenderung mempunyai kualitas hidup lebih baik terutama dari aspek hubungan sosial termasuk dukungan keluarga, sebaliknya keluarga tidak fungsional cenderung memiliki kualitas hidup yang kurang. Hasil penelitian Rosland (2015) di Michigan mengatakan bahwa terdapat pengaruh antara fungsi keluarga dengan kemandirian pasien diabetes. Fungsi keluarga yang tinggi berkaitan dengan tingkat dukungan keluarga yang lebih tinggi juga.

Temuan keempat yang dilakukan oleh Fatma Nuraisyah (2017) Berdasarkan hasil rata-rata nilai dukungan keluarga adalah baik dengan skala instrumen dalam penelitian ini disimpulkan bahwa responden terkadang mendapatkan dukungan keluarga. Rata-rata nilai kualitas hidup pasien DM tipe 2 adalah baik juga. Berdasarkan hasil ini dan disesuaikan dengan skala instrument dalam penelitian ini, diperoleh hasil bahwa responden merasa puas dengan kualitas hidup. Karakteristik responden berdasarkan umur, lama menderita DM tipe 2, dukungan keluarga dan kualitas hidup pasien DM tipe 2 menunjukkan bahwa adanya hubungan dukungan keluarga dengan kualitas hidup pasien DM tipe 2.

\section{Kualitas Hidup Penderita Diabetes Melitus Tipe 2}

Pada penelitian Ramkisson (2017) menyatakan bahwa kualitas hidup dapat berpengaruh terhadap dukungan keluarga yang mempunyai pengaruh positif terhadap kualitas hidup pasien diabetes khususnya dalam bentuk dorongan (encouragement) dari keluarga. Dengan demikian fungsi keluarga akan bertambah baik dan kualitas hidup pasienpun meningkat. Hasil penelitian Oktaviani (2018) juga menyatakan adanya hubungan antara dukungan keluarga dengan keaktifan pasien diabetes melitus dalam melakukan kontrol pemeriksaan gula darah. Intervensi keluarga terutama perilaku keluarga yang mendukung proses penyembuhan pasien. Dalam hal ini pengaruh psikososial dari keluarga lebih berpengaruh pada pengontrolan gula darah pasien dibandingkan hanya sekedar minum obat teratur.

Nuraisyah (2017) Menemukan adanya efek yang memengaruhi kualitas hidup pasien penyakit kronis. Bukan hanya psikologis, namun juga fisik, 
spiritual dan perilaku yang disesuaikan dengan kondisi pasien penyakit kronis. Kualitas hidup dinyatakan sebagai ukuran konseptual atau operasional mencakup kesejahteraan, kualitas kelangsungan hidup serta kemampuan untuk secara mandiri melakukan aktivitas seharihari yang sering digunakan dalam situasi penyakit akut ataupun kronik sebagai cara untuk menilai dampak terapi pada penderita.

\section{KESIMPULAN}

Hasil analisis literature dari dua tema besar yang telah teridentifikasi berdasarkan tinjauan pustaka yang sudah dilakukan kepada empat artikel yang diperoleh, dengan menggunakan metode analisis simplified approach empat arikel yang dibahas didapati hasil evaluasi tinjauan pustaka dapat disimpulkan dari dua tema besar yaitu dukungan keluarga dan kualitas hidup memiliki kategorinya masing-masing yang diperoleh menurut analisis yang peneliti lakukan. Hasil penelitian yang membahas tentang dukungan keluarga pada penderita DM tipe 2 terdapat hasil dukungan keluarga baik dan untuk kulitas hidup pada penderita DM tipe 2 didapatkan hasil cukup baik juga karena dari keempat artikel yang dipakai terdapat satu dari empat artikel yang memiliki hasil tidak ada hubungan dan tiga dari empat artikel mendapat hasil ada hubungan. Maka dapat disimpulkan dukungan keluarga dan kualitas hidup penderita DM tipe 2 memberikan hasil $(90 \%)$ baik dan rata-rata hasil dari keempat artikel ini menunjukan adanya hubungan dukungan keluarga dan kualitas hidup penderita DM tipe 2.
Hasil kajian literature ini diharapkan dapat menambah dan memberikan masukan positif untuk pengembangan ilmu keperawatan medikal bedah dan sebagai bahan untuk meneliti lebih lanjut bagi peneliti selanjutnya untuk menangani pemberian dukungan dengan melibatkan keluarga dalam perawatan pasien, mendorong keluarga untuk memberikan dukungan kepada pasien, mengedukasi keluarga terkait dampak dukungan yang diberikan terhadap kualitas hidup pasien.

\section{DAFTAR REFERENSI}

Andarmoyo dan Sulistyo. (2012). Keperawatan Keluarga, Konsep Teori, Proses dan

Praktik Keperawatan. Yogyakarta: Graha Ilmu

Aveyard, H. (2010). Doing a Literature Review in Health and Social Care: A Practical Guide (2nd Edition). New York: Open University Press.

Aveyard, H. (2014). Doing a literature review in health and social care: $A$ practical guide. Ed.3. Maidenhead: McGraw-Hill/Open University Press.

Classification Of Diabetes Mellitus. Geneva: World Health Organization; 2019. Licence: CC-BY- NC-SA 3.0 IGO

Decroli dan Eva. (2019). Diabetes Melitus Tipe 2. Padang: Pusat Penerbitan Bagian Ilmu Penyakit Dalam Fakultas Kedokteran Universitas Andalas

Donsu, J. (2014). Peran Faktor-Faktor Psikologis terhadap Depresi pada Pasien Diabetes Melitus Tipe 2. Jurnal Psikologis.

Desiningrum, D. (2010). Family's Social Support and Psychological Well Being of the elderly in Tembalang, 
Anima, Indonesia Psychological Journal, 26(1)

Dahlan, M. (2014). Statistik untuk Kedokteran dan Kesehatan Deskriptif, Bivariat, dan Multivariat, Dilengkapi Aplikasi Menggunakan SPSSS Edisi 6. Epidemiologi Indonesia.

Ernawati. (2013). Penatalaksanaan Keperawatan Diabetes Melitus Terpadu Dengan Penerapan Teori Keperawatan Self Care Orem. Jakarta: Mitra Wacana Media

Friedman, L. M. (2010). Buku ajar keperawatan keluarga: riset, teori, praktik (5th ed). Jakarta: EGC.

Fatma Nuraisyah. (2015) Family support and quality of life of diabetes mellitus patients in Panjatan II public health center, Kulon Progo.

Haastrup, E D. (2014). Family Support as Prodictor of Adherence to Diet Regimen among People with Type II Diabetes in Logos State. Journal of Nursing and Health Science.

Joanna Briggs Institute. (2016). Critical Appraisal Tools. Diakses dari http://joannabriggs.org/research/criti cal-appraisal-tools.

Ketut Suardana1. (2015). Hubungan Dukungan Sosial Keluarga Dengan Kualitas Hidup Pasien Diabetes Melitus Tipe II Di Puskesmas IV Denpasar Selatan.

Muklisin abi. (2012). Keperawatan Keluarga. Jogjakarta : Goysenn Publishing

Nursalam. (2015). Metologi Penelitian Ilmu Keperawatan: Pendekatan Praktis Edisi 4. Jakarta: Salemba Medika.

Nursalam. (2016). Metodologi Penelitian Ilmu Keperawatan: Penedekatan Praktis. Ed. Jakarta: Salemba Medika.
Pompili, M. (2009). Quality of life and suicide risk in patients with diabetes mellitus.

Rahayu, T. (2014). Hubungan Antara Dukungan Social Dengan Kesejahteraan Psikologis Pada Penderita Diabetes Melitus Tipe 2. Skripsi, Fakultas Psikologi Universitas Muhammadiyah Surakarta.

Samantha Ramkisson. (2017). Social support and coping in adults with type 2 diabetes.

Simamora, Janner P., 2012, Pengaruh Kateristik Dan Gaya Hidup Kelompok Dewasa Madya Terhadap Kejadian Hipertensi Di Wilayah Kerja Puskesmas Matiti Kabupaten Humbang Hasundutan. Tesis.

Smeltzer, S., Bare, B., Hinkle, J., \& Cheever, K. (2010). Brunner \& Suddarth Textbook of Medical - Surgical Nursing. Philadelphia: Wolters Kluwer Health.

Setiadi, (2008). Konsep dan Keperawatan keluarga. Surabaya : Graha Ilmu.

Setyaningsih, A. 2017. Kualitas Hidup Perawat Yang Menangani Pasien Tuberkolosis (Tb) Di Rumah Sakit.

Setiadi. (2008). Konsep \& Proses Keperawatan Keluarga. Yogyakarta: Graha Ilmu.

Skevington SM, Lotfy M, O'Connell KA. The World Health Organization's WHOQOL-BREF quality of life assessment: psychometric properties and results of the international field trial. A report from the WHOQOL group. Quality of life Research. 2004

Tim Riskesdas 2018. Laporan Nasional Riskesdas 2018. Jakarta: Lembaga 
Penerbit Badan Penelitian dan Pengembangan Kesehatan.

Vergnes, J. et al. (2010). Ethics in systematic reviews. Journal of Medical Ethics, 36(12), 771-774.

Wager, E., \& Wiffen, P. J. (2011). Ethical issues in preparing and publishing systematic reviews. Journal of Evidence-Based Medicine, 4(2), 130134. doi:10.1111/j.17565391.2011.01122.x

World Health Organization (2004). Introducing the WHOQOL Instruments. <depts.washington.edu/seaqol/docs/ WHOQOL_Info.pdf > [01 Januari 2015]

Williams, L., \& Hopper, P. (2015). Understanding Medical -Surgical
Nursing. Philadelphia: F. A. Davis Company.

World Health Organization. Introducing the WHOQOL Instruments. Geneva; 2004.

Yusra, A. (2010). Hubungan antara Dukungan Keluarga dengan Kualitas Hidup Pasien Diabetes Mellitus II di Poliklinik Penyakit dalam Rumah Sakit Umum Pusat Fatmawati. Thesis. [online], <lib.ui.ac.id/ file=digital.pdf $>$, Jakarta: Universitas Indonesia. Dipublikasikan.

Yusra, A. (2011). Hubungan antara dukungan keluarga dan kualitas hidup pasien DM tipe 2 di Poliklink Penyakit Dalam Rumah Sakit Umum Pusat Fatmawati Jakarta. Tesis 